УДК 070:93/94 (571.1)

DOI 10.25205/1818-7919-2018-17-6-22-31

\title{
Н. В. Жилякова
}

Томский государственный университет

пр. Ленина, 36, Томск, 634050, Россия

retama@yandex.ru

\section{СПЕЦИФИКА ПЕРЕДОВОЙ СТАТЬИ В САТИРИЧЕСКОМ ЖУРНАЛЕ «СИЛУЭТЫ ЖИЗНИ РОДНОГО ГОРОДА» $(1909$, ТОМСК) *}

\begin{abstract}
Анализируются передовые статьи томского сатирического журнала «Силуэты жизни родного города» (1909), написанные в форме пародийных «отчетов» о редакционной жизни. Рассматриваются история и структура журнала, определяются место и значение «отчетов», выявляются методы и приемы «маскировки» поднимаемых серьезных вопросов под юмористические описания жизни редакции. Делается вывод о том, что, используя пародийные «отчеты» вместо традиционных передовых статей, редакция журнала решала целый ряд задач: поднимала важные общественные проблемы, привлекала внимание своей потенциальной аудитории, раскрывала «внутреннюю кухню» редакционной жизни, интерес к которой возрос именно в начале XX в. в связи со становлением журналистики как массовой профессии. Исследование позволяет говорить о том, что журнал следовал традициям передовой сатирической журналистики, заложенным Н. И. Новиковым, Н. В. Гоголем, «искровцами» и развиваемым в начале XX в. в журнале «Сатирикон», а также выявляет взаимосвязь «большой» российской и региональной сатиры.

Ключевые слова: Томск, журналистика, «Силуэты жизни родного города», сатира.
\end{abstract}

\section{Введение}

Российская сатирическая журналистика начала ХХ в., пользовавшаяся неизменным интересом у советских ученых, находится в поле научной рефлексии и у современных исследователей. Можно выделить несколько направлений исследовательской работы, результаты которой становятся основой научных статей, монографий, диссертационных работ. Прежде всего это продолжающиеся библиографические изыскания, которые в основном касаются сатирической журналистики периода Первой русской революции 1905-1907 гг. (см., например: [Денисенко, 2015; Конёнкин, 2009; Вехова, 2017; Ерёмин, Шестерикова, 2014]). Сатирические журналы этого же периода являются главными источниками сведений по карикатуре [Сонина, 2017; Мойсинович, 2014; Голиков, 2016], по отдельным тематическим блокам о православном духовенстве [Леонов, 2014], о просвещении в Сибири [Кузнецова, 2014], о влиянии революции на развитие сатиры на Кавказе [Гаджиева, 2015] и др. При этом если, изучая сатиру периода Первой русской революции, ученые обращаются как к столичной, так и к провинциальной журналистике, то в работах, посвященных сатирической периодике 1910-х гг., рассматривается преимущественно один «Сатирикон» (и его продолжение - жур-

\footnotetext{
* Исследование проведено при финансовой поддержке РФФИ и Администрации Томской области в рамках научного проекта № 17-14-70006 «Словесная культура Сибири в общероссийском и европейском контекстах».
}

Жилякова Н. В. Специфика передовой статьи в сатирическом журнале «Силуэты жизни родного города» (1909, Томск) // Вестн. НГУ. Серия: История, филология. 2018. Т. 17, № 6: Журналистика. С. 22-31.

ISSN 1818-7919

Вестник НГУ. Серия: История, фрилология. 2018. Том 17, № 6: Журналистика

(C) Н. В. Жилякова, 2018 
нал «Новый Сатирикон») [Филиппова, 2014; Брызгалова, 2013; Костырева, 2013; Щербакова, 2005].

Такое неравномерное распределение исследовательского внимания связано, безусловно, с разным количеством материала для изучения: если в 1905-1907 гг. выходили сотни сатирических журналов, это время недаром считают одним из периодов расцвета русской сатиры, то в 1910-х гг. можно говорить лишь о единичных сатирико-юмористических изданиях, из которых самыми значимыми были журналы «сатириконцев».

Сложившаяся ситуация была характерна и для Сибири, и для Томска, являвшегося в начале XX в. крупным культурным, промышленным, торговым центром. Томская сатирическая журналистика была представлена многочисленными журналами периода Первой русской революции («Осы», «Ерш», «Красный смех», «Рабочий юморист» и др.) и отдельными сатирическими изданиями, выходившими в 1908-1912 гг.: газеты «Бенефисная газета» (1908) и «Синдетикон» (1912) и журнал «Силуэты жизни родного города» / «Силуэты Сибири» (1909-1910). Соответственно исследователи гораздо чаще обращаются к сатирическим журналам Томска 1905-1907 гг. (см., например: [Жилякова, 2014; Жилякова, Выгон, 2015] и др.), чем к томским изданиям периода реакции.

Одной из причин, по которой сатирические журналы и газеты 1908-1912 гг. редко оказываются в круге научной рефлексии, является отсутствие оригиналов изданий в местных томских архивах и библиотеках, а в интернет-пространстве на данный момент доступен лишь один оцифрованный номер журнала «Силуэты жизни родного города» (на сайте Томской областной библиотеки им. А. С. Пушкина по адресу http://elib.tomsk.ru/purl/1-7171/ - Силуэты жизни родного города. 1909. № 7 (28 февр.)). Остальные сохранившиеся номера журнала «Силуэты жизни родного города» (1909) и его продолжения «Силуэты Сибири» (1910) доступны в читальных залах РГБ и РНБ, где с ними работал автор исследования.

Цель настоящей статьи - выявление специфики жанра передовой статьи в сатирическом журнале «Силуэты жизни родного города» (Томск, 1909), «замаскированной» под пародийные отчеты о редакционной жизни. В числе решаемых задач обращение к истории возникновения и существования журнала, выявление структуры издания и места в ней жанра передовой статьи, анализ передовых статей «Силуэтов жизни родного города».

\section{Общая характеристика журнала}

Журнал «Силуэты жизни родного города» был основан в Томске А. Н. Козловским, который в 1908 г. получил разрешение от Главного управления по делам печати на издание еженедельного иллюстрированного журнала, посвященного жизни города и «местной злобе дня». Предполагалось, что в его программу войдут: «обзор местной жизни за неделю, рассказы, стихотворения, басни, сказки, биографии всех местных выдающихся деятелей, судебные процессы, злободневные фельетоны, отчеты заседаний городской думы, разных обществ и партий, театральные рецензии, сообщения корреспондентов, анекдоты, афоризмы, шутки, смесь, ответы редакции» ${ }^{1}$. Сменив нескольких издателей, в декабре 1909 г. журнал перешел в руки Вениамина Ивановича Романова, студента медицинского факультета Императорского Томского университета (об истории журнала см. подробнее: [Жилякова, 2016]).

Тираж журнала в 1909 г. составлял 600-800 экземпляров. Томский инспектор по делам печати характеризовал его следующим образом:

Этот еженедельный иллюстрированный юмористический журнал, осмеивая разного рода бытовые недостатки из жизни города Томска, главным образом, давал материалы, доставлявшие возможность читателю кое-что видеть в комическом освещении. Не касаясь вопросов политики, в разных рассказах журнал мог доставлять приятное развлечение. <...> Материальное положение «Силуэтов жизни родного города» было незавидно, так как от годичного издания получился дефицит, хотя и незначительный ${ }^{2}$.

«Силуэты...» отличались от своих предшественников - томских сатирических изданий многими нюансами: четкой ориентацией на общероссийский журнал «Сатирикон», работой

\footnotetext{
${ }^{1}$ ГАТО (Государственный архив Томской области). Ф. 3. Оп. 12. Д. 969. Л. 105.

${ }^{2}$ Там же. Д. 735. Л. 181.
} 
иллюстраторов, богатством сатирических жанров, представленных на его страницах, а кроме этого, сменой типологического статуса, поскольку в 1910 г. журнал «Силуэты жизни родного города» не только был переименован в «Силуэты Сибири», но и эволюционировал из сатирического в литературно-художественный иллюстрированный. Интересным новшеством было также введение в структуру журнала передовых статей, «замаскированных» под пародийные отчеты о работе редакции.

В объявлении о подписке на «Силуэты жизни родного города» в 1909 г. подробно расписывались журнальные отделы:

«Дневник томского обывателя» (обзор томской жизни за неделю).

«Преступление и наказание» (юридические недоразумения разных субъектов).

«Сцена и кулисы».

«Столбы отечества»: биографии и интервью всех выдающихся деятелей, будущих и бывших членов

Государственной Думы.

«Отцы города» (не смешивать со столбами отечества).

Фельетоны, фельетончики и фельетошки, современные, своевременные и злободневные.

Стихотворения на гражданские, военные и духовные темы.

«Около союзов и партий»: около потому, что на заседания некоторых обществ сотруднику так же

трудно проникнуть, как верблюду пройти игольные уши.

«В парламенте»- отчеты думских заседаний.

«Провинциальная почта» (отдел корреспонденций).

Анекдоты. Шутки. Басни. Афоризмы. Ответы редакции и прочее, способное вызвать хотя мимолетную улыбку (Силуэты. 1909. № 2).

Необходимо сказать, что далеко не все эти отделы встречались в каждом номере: видимо, список их максимально охватывал все задуманные редакцией направления.

Как видно из приведенного отрывка из объявления о подписке, передовая статья не была предусмотрена программой издания. Для сибирского сатирического журнала периода реакции передовая статья была жанром чрезвычайно сложным, поскольку и общественная обстановка, и цензурные условия не позволяли открыто обсуждать злободневные проблемы современности на страницах органа печати.

\section{Передовая статья как жанр дореволюционной периодики}

В современных энциклопедиях «передовая статья» определяется как «редакционное (реже авторское) публицистическое выступление, открывающее очередной номер периодического издания (газеты, журнала)» [Передовая статья, 1969-1978]. В советское время без такой «передовицы», освещающей «важнейшие актуальные события, задачи внутренней и внешней политики КПСС и Советского государства» не обходилось ни одно издание. Однако отметим, что передовая статья как газетный жанр зародилась задолго до советской эпохи. Впервые она появилась на страницах первой крупной частной русской газеты XIX в. «Северная пчела», издаваемой Ф. В. Булгариным. Именно в этой газете в 1857 г. в отделе «Новости заграничные» стали публиковаться передовые статьи, посвященные внешнеполитическим вопросам [Березина, 1965. С. 54]. Однако исследователи журналистики подчеркивают: «...передовая статья, выражающая позицию редакции по вопросам внутренней жизни, впервые появилась в газете "Молва" (1857). Эти передовые статьи носили открыто публицистический характер, поскольку формулировали основные положения определенного идейного течения (славянофильства) и были адресованы читателю-единомышленнику» [Там же].

Появление этого нового газетного жанра, «возникшего в пору общественного подъема 1860-х годов», было обусловлено, во-первых, «допущением в периодику с 1856 г. материалов на политические и общественные темы», а во-вторых, «более четкой дифференциацией общественного движения и общественной мысли по политическим направлениям» [Там же]. Термин «передовая статья» впервые был зарегистрирован только в 1865 г., в «Толковом словаре» В. Даля: «Передовая статья в газете, руководящая, содержащая обзор событий и их значения» [1865. С. 42].

Начиная с 1860-х гг. передовые статьи становятся привычным элементом структуры русских газет всех направлений и типов. Их отличали, по мнению исследователей, «три обяза- 
тельных элемента»: «современность, программность и публицистичность» [Березина, 1965. С. 55]. Однако они могли быть самых разных размеров и форм, иметь различное содержание, структуру и т. д. В томском журнале «Силуэты жизни родного города» место передовых статей заняли пародийные «отчеты» о редакционной жизни.

\section{«Все важнейшие вопросы...»}

В 1909 г. в журнале были опубликованы следующие «отчеты»:

- О.С.Р.К.П.Ж. // Силуэты. 1909. № 1;

- Кризис (редакционный этюд) // Силуэты. 1909. № 17;

- Несколько теплых слов (от редакции) // Силуэты. 1909. № 27;

- Редакционное совещание // Силуэты. 1909. № 34;

- От редакции // Силуэты. 1909. № 43.

Особняком в журнале стояла статья «От редакции», опубликованная в № 20 журнала «Силуэты Сибири» в 1910 г., - она не носила сатирического характера, была посвящена итогам выхода журнала в текущем году.

Первая статья под названием «О.С.Р.К.П.Ж.» располагалась на месте традиционной редакционной (или передовой) статьи и, по сути, являлась программой издания. Ее необычный заголовок пояснялся редакцией следующим образом:

Опытный наборщик, взглянув на заголовок статьи, заявил, что так номер не пройдет. - Почему?..

- А особое положение?.. За такие словеса Нарыма не желаете?

- Какие?

- Я, говорит, разве не понимаю: объявление социал-революционной и кадетской партии, на жизнь и на смерть.

- С ума спятил?.. Теперь так принято сокращать длинные названия. Читай: организационное совещание редакционного комитета по изданию журнала» (Силуэты. 1909. № 1).

В этом небольшом отрывке обыгрывалось повышенное внимание цензуры к периодической печати, поиск «крамолы» и скрытых «революционных» смыслов в любых непонятных словах и сокращениях; пародировалась «мода» на длинные названия и составление причудливых аббревиатур; акцентировалось внимание на «особом положении» Томской губернии, во время которого журналы находились под особым контролем, что вынуждало их быть особенно осторожными в высказываниях. Таким образом, буквально с самого начала, с заголовка, читатель вовлекался в игру по «расшифровке», по угадыванию «двойного дна» в высказываниях журналистов.

Статья «О.С.Р.К.П.Ж.» была написана от имени «Секретаря», который объявил о своем решении следовать принципу «ничего тайного от читателя». Взяв за основу «стиль сообщений телеграфного агентства о ходе заседаний Государственной Думы», он подробно описал первое заседание редакции, на котором «решались все важнейшие вопросы, касающиеся существования журнала» (Силуэты. 1909. № 1).

Воплощение заявленного принципа («ничего тайного») было реализовано прежде всего в описании угощения:

На столе стоял самовар, закуска и шесть бутылок... с мадерой, № 36, хересом, № 55, коньяком Шустова, запеканкой, рябиной и английской горькой, большой графин с водкой.

Кроме этого, от имени «Секретаря» в тексте шли реплики, заключенные в скобки, комментирующие происходящее:

- (требуют исключить пункт о вине. Не желаю и поясняю, что еще был принесен второй графин очищенной);

- (заявляют, что вставками нарушаю единство впечатлений. Наплевать на единство, раз оно расходится с фотографией момента);

- ...прожевывая кусок колбасы, невнятно заявил второй оратор (Протестует. Ну, хорошо, добавляю: когда прожевал, то говорил внятно и с приятностию)

и т. д. (Силуэты. 1909, № 1). 
«Алкогольный» декор и юмористические реплики обрамляли редакционные диалоги о направлении журнала. И за юмористической формой обнаруживались серьезные проблемы, которые пыталась решить редакция на своем - реальном или выдуманном - совещании.

Первый вопрос, поставленный на совещании, - это отсутствие единой партийной платформы у редакции:

В совещании принимали участие шесть членов-организаторов. При вопросе о направлении журнала произошел спор, из которого выяснилось, что два члена комитета - октябристы, два - кадеты, один - «левее» и один умеренный беспартийный (требуют уничтожения указаний партийности. Ни за что: еже писах - писах). Ввиду такого деления голосов и «особого положения», сужающего широкие взгляды, peшено воздержаться от политических тем, всецело предоставив их обсуждение Государственной Думе, и говорить на местную злобу дня (Силуэты. 1909, № 1).

Подчеркивая, что в состав редакции входили представители разных политических направлений, журналисты отстаивали свое право на «внепартийность» и в то же время акцентировали внимание на главной редакционной установке - «говорить на местную злобу дня». Хотя следует добавить, что редакция находила способы разговора на политические темы, пользуясь средствами сатиры.

Вторым принципом, обсужденным редакцией, стало «привлечение к суду общества, к суду совести, известных грязных, порочных элементов и лиц, душителей справедливости, преследование их со всею беспощадностью, указание пальцем» (Силуэты. 1909. № 1). В этой цитате прямо чувствовалось следование идеологии «Искры», знаменитого сатирического журнала 1860-х гг., который проповедовал «своеобразный террор по отношению к властям всех рангов» [Ямпольский, 1965. С. 166], а также требование сатиры на «лица» (вслед за новиковским «Трутнем»).

Однако редакция томского журнала считала, что действовать в этом направлении следовало осторожно:

Ударь человека публично в физиономию - ожесточится; ничего доброго от такого приема не будет.

Единственное пугало для всякой хищной и озорной птицы - смех; единственное наше оружие - насмешка. Не думайте, что эти удары легки. Раны, наносимые ими, болезненны и называются пренебрежением и презрением.

Будем смеяться так, чтобы «сквозь видимый миру смех слышались незримые слезы». Это - первое. Второе - выступим на защиту «всех судьбой гонимых». Пусть каждый униженный и оскорбленный найдет у нас помощь (общий шум. Крики - Найдет! Найдет!). Предложение выпить за гонимых судьбой принято большинством пяти против одного (Силуэты. 1909. № 1).

Последние «тосты» участников заседания были связаны с правдой («за правдивые Силуэты жизни!»), с чествованием «всех честных и добрых людей, которые живут в Томске»; «далее пошла уже сухая материя, выраженная лаконически в следующих тезисах»:

Приняться за самую основательную чистку всех темных углов города и тащить оттуда на свет Божий всю плесень и гниль, которая как огня его боится.

Избегать, по возможности, старого, избитого тракта и идти новой дорогой.

Не изображать из себя непогрешимых жрецов истины - первородный грех всех редакций, - памятуя, что тот не ошибается, кто ничего не делает, и откровенно признаваться в допущенных промахах.

Всеми силами стремиться к правде, добру и красоте! (Силуэты. 1909. № 1).

Таким образом, первый пародийный «отчет» о редакционной жизни являлся полноценной передовой статьей, поскольку он касался главных принципов, сформулированных журналом в отношении его направления. Выбранная форма пародии позволила, с одной стороны, смягчить остроту высказываний, с другой - сделала текст более «легким» для восприятия той массовой аудиторией, на которую ориентировался журнал: основным читателем журнала был городской обыватель, которому была более чем близка тема «дружеской попойки», заседания, щедро сдобренного алкоголем.

Остальные редакционные «отчеты» описывали собрания редакционного комитета по разным поводам жизни журнала. «Редакционный этюд» «Кризис» (Силуэты. 1909. № 17) был посвящен отказу редактора от своего поста и побегу его из редакции; «Несколько теплых 
слов» (Силуэты. 1909. № 27) - обсуждению ужесточения редакционной политики по отношению к мошенникам; «Редакционное совещание» (Силуэты. 1909. № 34) - итогам выборов в городскую думу; «От редакции» (Силуэты. 1909. № 43) - «редакционному объяснению» по итогам первого издательского года. Все они следовали одному и тому же принципу: юмористическое описание действий сотрудников (всегда обозначающихся только псевдонимами), шуточные реплики автора «отчетов», которые «маскировали» постановку важных общественных вопросов: о невозможности «независимой журналистики» в условиях реакции, о работе томской думы, о проблемах городской жизни и т. д. С другой стороны, эти материалы приоткрывали для читателей «внутреннюю кухню» редакционной жизни, знакомили с журналистами, которые испытывали те же проблемы, что и обычные горожане: вынуждены были снимать квартиры - и не всегда могли в срок их оплатить; ездили на извозчиках, когда были деньги, и мокли под дождем в их отсутствие, и т. д. Так, например, в статье «Редакционное совещание» журналисты так описывали свое положение:

Оказалось, что все сотрудники по вине думы платили за квартиры на $50 \%$ дороже, чем они стоят на окраинах, на последних же жили только трое: Бернарден, разорвавший во время путешествия по Заплоту среднюю часть нового костюма; Зиг-Заг, оставивший в безднах Уржатки 3 пары галош и сапог, и Або-Риген, который отдал пальто несчастным пролетариям, встретившим его у одного потухающего фонаря (Силуэты. 1909. № 34).

На протяжении 1909-1910 гг. в «Силуэтах...» было использовано около 20 псевдонимов. Это «Хмурый», «Тихий мальчик», «Зиг-Заг», «Премудрая крыса Онуфрий», «Бой-кот», «Бернарден де Сент Пьер», «Точечка», «Юс», «Мина», «Миша Буфф», «Ив. Ив. Иванов» и др. Некоторые из них принадлежали достаточно известным в Томске авторам: так, псевдонимом «Премудрая крыса Онуфрий» подписывался сатирик Порфирий Алексеевич Казанский, сотрудник многих томских изданий. Псевдонимы использовались и для подписи карикатур («Фон Клякс», «М.Щ.» и др.). В 1910 г. на страницах журнала стали появляться фамилии известных поэтов и писателей Томска: Г. А. Вяткин, И. Хейсин, С. Чеботарь, П. Ильинский, В. Курицын и др., что было связано с переменой типологического статуса издания, попыткой совместить в рамках одного журнала литературно-художественное и юмористическое направления.

В пародийных «отчетах» обращало на себя внимание сочетание реальных фактов и гротескных персонажей, гиперболизированных ситуаций, карикатурных образов. Так, реальный факт - смена редактора в 1909 г. - в описании журнала выглядела как его «бегство», исчезновение, во время которого он «мгновенно из шестнадцати пар калош выбрал свои» (Силуэты. 1909, № 17); обсуждение в редакции деятельности городской думы закончилось тем, что журналисты «стали располагаться на ночной отдых бивуаком, расстилая на столы и стулья, составленные в каре, пальто, пиджаки и тому подобные вещи» (Силуэты. 1909. № 34), и т. д. Этот прием давал возможность затрагивать самые острые темы, маскируя их под выдуманные, юмористические ситуации.

\section{Заключение}

Таким образом, редакция «Силуэтов жизни родного города», используя форму пародийных редакционных «отчетов», решала целый ряд задач: поднимала важные общественные проблемы, привлекала внимание своей потенциальной аудитории, раскрывала «внутреннюю кухню» редакционной жизни, интерес к которой возрос именно в начале ХХ в. в связи со становлением журналистики как массовой профессии. В статьях четко прослеживалась установка на традиции передовой сатирической журналистики, заложенные Н. И. Новиковым, Н. В. Гоголем, «искровцами» и развиваемые в начале XX в. в журнале «Сатирикон». Как отмечали исследователи, говоря о специфике «старшего собрата» томского журнала, о «Сатириконе»: «Писатели-сатириконцы обращались к тому, что было интересно их читателю: политическим преобразованиям и жизни обычного человека. Полностью высказывать свое мнение относительно внутренней и внешней политики страны сатириконцы не могли из-за жесткого контроля цензуры. Однако очерки общественных нравов, картины жизни города, обращение к актуальным проблемам современности читатели встречали в каждом вы- 
пуске» [Костырева, 2013. С. 97]. Этим же принципам следовал и журнал «Силуэты жизни родного города». При этом в журнале «Силуэты Сибири», в который эволюционировали «Силуэты жизни родного города», подобные «отчеты» были уже невозможны из-за смены характера журнала, снижения его сатирической составляющей и усиления литературно-художественного направления.

Пародийные «отчеты» о редакционной жизни журналистов, используемые томскими сатириками в качестве передовых статей журнала «Силуэты жизни родного города», представляют собой замечательные образцы сибирской словесности начала XX в. Они позволяют исследователям проследить взаимосвязь «большой» российской сатиры и провинциальной, региональной, и заслуживают дальнейшего изучения.

\section{Список литературы}

Березина В. Г. Газеты 1860-х годов // Очерки по истории русской журналистики и критики. Л.: Изд-во Ленингр. ун-та, 1965. Т. 2: Вторая половина XIX века. С. 30-59.

Брызгалова Е. Н. Творчество сатириконцев и русская эстрада // Вестн. Твер. гос. ун-та. Серия: Филология. 2013. № 6. С. 13-19.

Вехова A. B. Коллекция сатирических журналов Первой русской революции в отделе редкой книги ККУНБ ИМ. А. С. Пушкина: хранение, изучение, введение в научный оборот // Семнадцатые Кайгородовские чтения. Культура, наука, образование в информационном пространстве региона: Сб. материалов Всерос. науч.-практ. конф. с международным участием / Гл. ред. С. С. Зенгин. Краснодар, 2017. С. 14-16.

Гаджсиева Л. О. Влияние Первой русской революции на развитие сатирической печати на Кавказе // Вестн. Пятигор. гос. ун-та. 2015. № 2. С. 135-141.

Голиков А. Г. Рисунок и текст в политической карикатуре отечественных дореволюционных сатирических журналов // История отечественных СМИ. Ежегодник. М., 2016. Т. 1, вып. 1. С. 17-29.

Даль В. И. Толковый словарь живого великорусского языка. 1-е изд. СПб.; М.: Изд. товарищества М. О. Вольф, 1865. Т. 3.

Денисенко Е. П. Виленские сатирические журналы 1906-1908 гг. (по материалам библиотеки РАН) // Берковские чтения - 2015. Книжная культура в контексте международных контактов: Материалы III Междунар. науч. конф. М.: Наука, 2015. С. 146-152.

Ерёмин М. А., Шестерикова В. В. О первом самарском сатирическом еженедельнике «Горчишник», 1906 г. // Вестник архивиста. 2014. № 2. С. 129-145.

Жилякова Н. В. «И смех, и горе»: неизвестный сатирический журнал Томска периода Первой русской революции // Вестн. Том. гос. ун-та. Филология. 2014. № 2 (28). С. 160-168.

Жилякова Н. В. К истории томского журнала «Силуэты жизни родного города» (1909) «Силуэты Сибири» (1910) // Вестн. Том. гос. ун-та. Филология. 2016. № 2 (40). С. 147-160.

Жилякова Н. В., Выгон Л. С. Традиции новиковской сатиры в томском журнале «Ерш» (1906-1907 гг.) // Вестн. Том. гос. ун-та. Филология. 2015. № 2 (34). С. 184-194.

Конёнкин С. В. Сатирические журналы России начала XX в. // Библиография. Науч. журн. по библиографоведению, книговедению и библиотековедению. 2009. № 2. С. 101-108.

Костырева О. В. «Массовый» человек на страницах журнала «Сатирикон» // Филологические науки. Вопросы теории и практики. 2013. № 10 (28). С. 96-99.

Кузнецова T. А. Просвещение в Сибири на страницах сатирических еженедельных журналов рубежа XIX-XX вв. // Сибирский педагогический журнал. 2014. № 2. С. 146-149.

Леонов Д. Е. Православное духовенство на страницах сатирических журналов периода Первой российской революции (по материалам Ярославской губернии) // Вестн. Костром. гос. ун-та. 2014. Т. 20. № 4. С. 71-75.

Мойсинович А. М. Приемы использования политической карикатуры и аллегорий в сатирических журналах Ярославской губернии в годы Первой русской революции // Вестн. Ярослав. гос. ун-та им. П. Г. Демидова. Серия Гуманитарные науки. 2014. № 1. С. 23-26.

Передовая статья // Большая советская энциклопедия. М.: Советская энциклопедия, 19691978. URL: http://enc-dic.com/enc_sovet/Peredovaja-statja-47057.html (дата обращения 25.01. 2018). 
Сонина E. C. А.С. Пушкин в карикатуре XIX - середины XX века // Болдинские чтения 2017: Сб. ст. Междунар. науч. конф. / Национальный исследовательский Нижегородский государственный университет им. Н. И. Лобачевского. Н. Новгород, 2017. С. 91-101.

Филиппова T. A. Кавказский фронт в русской журнальной сатире эпохи Первой мировой войны. По материалам журнала «Новый Сатирикон» // Восточный архив. 2014. № 1 (29). C. $40-46$.

Щербакова A. В. Создание иронии средствами лексики и фразеологии в художественной прозе авторов «Сатирикона» // Вестн. Костром. гос. ун-та. 2005. Т. 11, № 1. С. 37-40.

Ямпольский И. Г. Сатирические журналы 1860-х годов («Искра», «Гудок», «Будильник») // Очерки по истории русской журналистики и критики. Л.: Изд-во Ленингр. ун-та, 1965. Т. 2: Вторая половина XIX века. С. 151-182.

Материал поступил в редколлегию 29.01.2018

\author{
N. V. Zhilyakova \\ National Research Tomsk State University \\ 36 Lenin Str., Tomsk, 634050, Russian Federation \\ retama@yandex.ru
}

\title{
THE SPECIFICITY OF THE ADVANCED ARTICLE IN THE SATHYRIC MAGAZINE «SILHOUETTES OF LIFE OF THE NATIVE CITY» (1909, TOMSK)
}

The article analyzes the advanced articles of the satirical magazine «Silhouettes of life of the native city», founded in 1909 in the city of Tomsk. It differed from other Tomsk satirical journals with a clear focus on the all-Russian magazine Satirikon, the work of illustrators, the wealth of satirical genres presented on its pages, and, in addition, the change of typological status, since in 1910 the magazine «Silhouettes of life of the native city» was not only renamed the «Silhouettes of Siberia», but also evolved from the satirical into the literary and artistic illustrated. The editorial was not provided for in the publication program: for the Siberian satirical periodical of the reaction period, this was an extremely complex genre, since both the social situation and censorship conditions did not allow openly discussing topical problems of our time on the pages of the press. Therefore, an interesting innovation was also the introduction of the editorial structure of the editorial articles, "disguised» for parodic reports on the work of the editorial board. The study analyzes the specifics of these «reports», reveals the methods and techniques of «disguising» the serious issues raised under humorous descriptions of the editorial life. Already the first parodic «report» on the editorial life, published in the first issue of the Silhouettes... was a full-fledged editorial, as it concerned the main principles formulated by the journal with regard to its direction. The chosen form of parody allowed, on the one hand, to soften the severity of statements, on the other - made the text more «easy» for perception by the mass audience on which the journal was oriented. The remaining editorial «reports» described the meetings of the editorial committee on various occasions of the journal's life. This is the editor's refusal from his post and his «escape» from the editorial office; discussion of the tightening of editorial policy in relation to scammers; analysis of the results of elections to the city duma, etc. All of them followed the same principle: a humorous description of the actions of employees (always denoted only by pseudonyms), humorous replicas of the author of the «reports» that «masked» the posing of important public issues: the impossibility of «independent journalism» under conditions of reaction, the work of the Tomsk Duma, about the problems of city life, etc. It is concluded that, using parodic «reports» instead of traditional editorials, the magazine's editorial team solved a number of problems: raising important public problems, attracting the attention of its potential audience, revealing the «inner kitchen» of the editorial life, the interest in which grew at the beginning XX century in connection with the formation of journalism as a mass profession. The study allows us to talk about the magazine following the traditions of advanced satirical journalism, laid down by N. I. Novikov, N. V. Gogol, «Iskra-ists» and developed in the 
early XX century in the journal «Satyricon», reveals the relationship of «great» Russian and regional satire.

Keywords: Tomsk, journalism, «Silhouettes of the life of the native city», satire.

\section{References}

Berezina V. G. Gazety 1860-kh godov [The newspaper of the 1860s]. Ocherki po istorii russkoi zhurnalistiki $i$ kritiki [Essays on the history of Russian journalism and criticism]. Leningrad, Izd-vo Leningrad State Uni. Press, 1965, vol. 2: The second half of XIX century, p. 30-59. (in Russ.)

Bryzgalova E. N. Tvorchestvo satirikontsev i russkaya estrada [Satirikont's creativity and Russian stage music]. Vestnik Tverskogo gosudarstvennogo universiteta. Seriya: Filologiya [Bulletin of Tver State University. Series: Philology], 2013, № 6, p. 13-19. (in Russ.)

Dal V. I. Tolkovyi slovar zhivogo velikorusskogo yazyka [The explanatory dictionary of a living Great Russian language]. $1^{\text {st }}$ ed. St. Petersburg, Moscow, Izdanie tovarishhestva M. O. Volf, 1865, vol. 3, p. 42. (in Russ.)

Denisenko E. P. Vilenskie satiricheskie zhurnaly 1906-1908 gg. (po materialam biblioteki RAN) [Vilensky satirical journals of 1906-1908. (based on the materials of the RAS library)]. Berkovskie chteniya - 2015. Knizhnaya kultura $v$ kontekste mezhdunarodnych kontaktov [Berkovsky readings 2015. Book collation in the context of international contacts]. Materials of the Institute of Intern. Scientific Conf. Moscow, Nauka, 2015, p. 146-152. (in Russ.)

Eryomin M. A., Shesterikova V. V. O pervom samarskom satiricheskom ezhenedelnike «Gorchishnik», 1906 g. [About the first Samara satirical weekly «Gorchishnik», 1906]. Vestnik archivista [Archivist's Newsletter], 2014, № 2, p. 129-145. (in Russ.)

Filippova T. A. Kavkazskii front v russkoi zhurnal'noi satire epochi Pervoi mirovoi voiny. Po materialam zhurnala «Novyi Satirikon» [The Caucasian front in the Russian magazine satire of her epoxy of the First World War. Based on the materials of the magazine «New Satyricon»]. Vostochnyi archiv [Eastern Archive], 2014, № 1 (29), p. 40-46. (in Russ.)

Gadzhieva L. O. Vliyanie Pervoi russkoi revolyucii na razvitie satiricheskoi pechati na Kavkaze [The Influence of the First Russian Revolution on the Development of the Satyric Press in the Caucasus]. Vestnik Pyatigorskogo gosudarstvennogo universiteta [Bulletin of Pyatigorsk State University], 2015, № 2, p. 135-141. (in Russ.)

Golikov A. G. Risunok i tekst v politicheskoi karikature otechestvennych dorevolyutsionnych satiricheskich zhurnalov [Figure and text in the political caricature of domestic pre-revolutionary satirical magazines]. Istoriya otechestvennykh SMI. Ezhegodnik 2016 [History of domestic media. Yearbook 2016]. Moscow, MGU Press, 2016, vol. 1, no. 1, p. 17-29. (in Russ.)

Konyonkin S. V. Satiricheskie zhurnaly Rossii nachala XX v. [The satirical journal of Russia at the beginning of the 20th century]. Bibliografiya. Nauchnyi zhurnal po bibliografovedeniyu, knigovedeniyu i bibliotekovedeniyu [Bibliography. Scientific journal on bibliography, bibliology and library science], 2009, № 2, p. 101-108. (in Russ.)

Kostyreva O. V. «Massovyi» chelovek na stranitsach zhurnala «Satirikon» [«Mass» in the pages of the magazine «Satyricon»]. Filologicheskie nauki. Voprosy teorii i praktiki [Philological Sciences. The Question of Theory and Practice], 2013, № 10 (28), p. 96-99. (in Russ.)

Kuznetsova T. A. Prosveshchenie v Sibiri na stranitsach satiricheskich ezhenedel'nych zhurnalov rubezha XIX-XX vv. [Enlightenment in Siberia on the pages of satirical weekly journals at the turn of the $19^{\text {th }}$ and $20^{\text {th }}$ centuries]. Sibirskii pedagogicheskii zhurnal [Siberian Pedagogical Journal], 2014, № 2, p. 146-149. (in Russ.)

Leonov D. E. Pravoslavnoe duchovenstvo na stranitsach satiricheskich zhurnalov perioda Pervoi rossiiskoi revolyutsii (po materialam Yaroslavskoi gubernii) [The Orthodox clergy on the pages of satirical magazines of the First Russian Revolution (based on the materials of the Yaroslavl Province)]. Vestnik Kostromskogo gosudarstvennogo universiteta [Bulletin of the Kostroma State University], 2014, vol. 20, no. 4, p. 71-75. (in Russ.)

Moisinovich A. M. Priemy ispol'zovaniya politicheskoi karikatury i allegorii v satiricheskich zhurnalach Yaroslavskoi gubernii v gody Pervoi russkoi revolyutsii [The use of political caricature and allegory in the satirical magazines of the Yaroslavl Province in the year of the First Russian Revolution]. Vestnik Yaroslavskogo gosudarstvennogo universiteta im. P. G. Demidova. Seriya 
Gumanitarnye nauki [Bulletin of Yaroslavl State University. P. G. Demidov. Series Humanities], 2014, no. 1, p. 23-26. (in Russ.)

Peredovaya stat'ya [Advanced article]. Bol'shaya sovetskaya entsiklopediya [Great Soviet encyclopedia]. Moscow, Sovetskaya entsiklopediya, 1969-1978. Available at: http://enc-dic.com/ enc_sovet/Peredovaja-statja-47057.html (25.01.2018) (in Russ.)

Shcherbakova A. V. Sozdanie ironii sredstvami leksiki i frazeologii v chudozhestvennoi proze avtorov «Satirikona» [Creation of irony by means of vocabulary and phraseology in the artistic prose of the authors of «Satyricon»]. Vestnik Kostromskogo gosudarstvennogo universiteta [Bulletin of the Kostroma State University], 2005, vol. 11, no. 1, p. 37-40. (in Russ.)

Sonina E. S. A. S. Pushkin v karikature XIX - serediny XX veka [Pushkin in the caricature of the twentieth - the middle of the twentieth century]. Boldinskie chteniya 2017 [Boldin Readings 2017]. Sat. Art. International Scientific Conf. Nizhnii Novgorod, 2017, p. 91-101. (in Russ.)

Vekhova A. V. Kollektsiya satiricheskich zhurnalov Pervoi russkoi revolyucii v otdele redkoi knigi KKUNB im. A. S. Pushkina: chranenie, izuchenie, vvedenie v nauchnyi oborot [Collection of satirical magazines of the First Russian Revolution in the department of the rare book KKUNB im. A. S. Pushkin: storage, study, introduction to the scientific revolution]. Semnadtszatye Kaigorodovskie chteniya. Kul'tura, nauka, obrazovanie $v$ informacionnom prostranstve regiona [The seventeenth of the Kaigorod Readings. Culture, science, education in the information space of the region]. Sat. Materials All-Russia Scientific and Practical Conf. with international. participation. Ed. by S. S. Zengin. Krasnodar, 2017, p. 14-16. (in Russ.)

Yampolskii I. G. Satiricheskie zhurnaly 1860-kh godov («Iskra», «Gudok, «Budil`nik») [The satirical journal of the 1860s (Iskra, Gudok, The Alarm Clock)]. Ocherki po istorii russkoi zhurnalistiki $i$ kritiki [Essays on the history of Russian journalism and criticism]. Leningrad, Leningrad State Uni. Press, 1965, vol. 2: Second half of the twentieth century, p. 151-182. (in Russ.)

Zhilyakova N. V. «I smech, i gore»: neizvestnyi satiricheskii zhurnal Tomska perioda Pervoi russkoi revolyutsii [«And laughter and sorrow»: the unknown satirical journal of Tomsk during the First Russian Revolution]. Vestn. Tom. gos. un-ta. Filologiya [Bulletin of Tomsk State University. Philology], 2014, № 2 (28), p. 160-168. (in Russ.)

Zhilyakova N. V. K istorii tomskogo zhurnala «Siluety zhizni rodnogo goroda» (1909) «Siluety Sibiri» (1910) [To the history of the Tomsk magazine «Silhouettes of life of the native city» (1909) - «Silhouettes of Siberia» (1910)]. Vestn. Tom. gos. un-ta. Filologiya [Bulletin of Tomsk State University. Philology], 2016, № 2 (40), p. 147-160. (in Russ.)

Zhilyakova N. V., Vygon L. S. Traditsii novikovskoi satiry v tomskom zhurnale «Ersh» (19061907 gg.) [Traditions of Novikov's satire in the Tomsk magazine «Yersh» (1906-1907)]. Vestn. Tom. gos. un-ta. Filologiya [Bulletin of Tomsk State University. Philology], 2015, № 2 (34), p. 184194. (in Russ.)

\section{For citation:}

Zhilyakova N. V. The Specificity of the Advanced Article in the Satirical Magazine «Silhouettes» of Life of the Native City (1909, Tomsk). Vestnik NSU. Series: History and Philology, 2018, vol. 17, no. 6: Journalism, p. 22-31. (in Russ.)

DOI 10.25205/1818-7919-2018-17-6-22-31 